\title{
Pengaruh Metode Pembelajaran dan Sikap Sosial Terhadap Hasil Belajar Sejarah Siswa SMAN 12 Tangerang Selatan
}

\author{
Oleh : Naijan \\ Universitas Negeri Jakarta \\ naijan.lkg@gmail.com
}

\begin{abstract}
The aim of the study is to reveal the empirical data about the effect of instructional methodology and student's social attitudeon the outcome of history learning on the students of SMAN 12 Tangerang Selatan. The methodology used is the experimental method with a $2 x 2$ treatment design. Research instrumentation will include a test that will be used to measure student's learning outcome, and a questionnaire that will be used to measure student's social attitudeon history outcomes. A total of 36 participants will be randomly selected. Data analysis will be performed by using two way variance analysis. The findings of the study will be demonstrate: 1) a higher student's history learning outcome of those who were taught by Cooperative Learning method typeJigsawcompared to those who were taught by conventional method. 2) There is an interaction effect between instructional methodology and student's social attitudeon history learning outcome. 3) History learning outcome of students who has positive social attitudeand were taught by Cooperative Learning method typeJigsaware higher than those with the same level of social attitude but were taught by conventional method. 4) History learning outcome of students who has negative social attitudeand were taught by Cooperative Learning method typejigsaware not below those with the same social attitude but were taught by conventional method.
\end{abstract}

Keywords : history learning outcome, history instructional methodology, student's social attitude, cooperative learning methodtipe Jigsaw, cooperative learning

\begin{abstract}
Abstrak
Tujuan penelitian ini adalah untuk mendapatkan data empiris tentang pengaruh metode Cooperative Learning tipe Jigsawdan sikap sosial terhadap hasil belajar Sejarah siswa SMA Negeri 1 Kota Tangerang Selatan. Metode yang digunakan adalah metode eksperimen dengan rancangan Treatment By Level $2 \times 2$. Insrumen yang digunakan adalah tes untuk mengukur hasil belajar dan kuisioner untuk megukur sikap sosial siswa dalam pembelajaran Sejarah. Sampel diambil 36 siswa untuk kelas eksperimen. Analisa data menggunakan ANAVA dua jalur. Hasil penelitian menunjukkan bahwa: 1) Terdapat perbedaan yang signifikan hasil belajar antara siswa yang mendapat pembelajaran dengan menggunakan metode Cooperative Learning tipe Jigsawdan metode Konvensional; 2) Terdapat pengaruh interaksi antara penggunaan metode pembelajaran dan sikap sosial siswa terhadap hasil belajar sejarah siswa; 3) Terdapat perbedaan yang signifikan hasil belajar sejarah bagi siswa yang mempunyai sikap sosial positif jika diberikan pembelajaran dengan metode Konvensional dan metode Cooperative Learning tipe Jigsaw; 4) Terdapat perbedaan yang signifikan hasil belajar sejarah bagi siswa yang mempunya sikap sosial negatif jika diberikan pembelajaran dengan metode Konvensional dan metode Cooperative Learning tipe Jigsaw.
\end{abstract}

Kata kunci : hasil belajar sejarah, metode pembelajaran sejarah, sikap sosial siswa, cooperative learning tipe Jigsaw, pembelajaran kooperatif 


\section{Pendahuluan}

\section{Latar Belakang Masalah}

Pembelajaran Sejarah saat ini kurang memenuhi standar hasil yang memuaskan. Berdasarkan survei pendahuluan, Sejarah adalah salah satu mata pelajaran dengan nilai tes sumatif yang rendah. Nilainya masih dibawah KKM (Kriteria Ketuntasan Minimal) sehingga untuk mencapai KKM, sebagian besar siswa harus melalui proses remedial. Siswa masih menganggap Sejarah sebagai mata pelajaran yang tidak penting, Kondisi ini mengakibatkan rendahnya minat dan motivasi belajar siswa terhadap pelajaran sejarah, sehingga ketika diadakan penilaian secara obyektif, nilai mata pelajaran sejarah rata-rata rendah atau dibawah KKM. Rendahnya minat dan motivasi belajar ini mengakibatkan rendahnya hasil belajar.

Situasi ini melanda kegiatan pembelajaran sejarah di SMA Negeri 12 Tangerang Selatan hingga saat ini. Nilai rata-rata hasil UKK (Ujian Kenaikan Kelas) hanya 64,05. Padahal KKM yang sudah ditentukan sebesar 75. Metode Pembelajaran konvensional yang diterapkan selama ini belum bisa meningkatkan prestasi belajar sejarah siswa. Metode konvensional yang sangat umum dan terlalu dominan digunakan dalam pembelajaran ternyata membuat siswa jenuh sehingga minat belajar sejarah siswa tetap rendah.Akibatnya dari waktu ke waktu, prestasi belajar Sejarah siswa SMA Negeri 12 Tangerang Selatan tidak pernah mengalami peningkatan.

Merujuk kondisi diatas, diperlukan metode alternatif dalam pembelajaran sejarah. Penggunaan metode alternatif ini diharapkan dapat meningkatkan minat dan motivasi belajar sejarah para siswa.Meningkatnya minat dan motivasi belajar, diharapkan pada akhirnya akan meningkatkan hasil belajar siswa. Metode pembelajaran alternatif yang dimaksud disini adalah Metode Cooperative Learning tipe Jigsaw.

Metode Cooperative Learning tipe Jigsaw adalah metode yang mengedepankan kerja sama, kekompakan dan toleransi sesama siswa. Metode ini sesuai diterapkan dalam pembelajaran sejarah karena tujuan pelajaran Sejarah diantaranya menanamkan nilai persatuan dan kesatuan.

Beberapa alasan pemilihan Metode Cooperative Learning tipe Jigsaw. Pertama, Metode Cooperative Learning tipe Jigsaw memposisikan siswa secara aktif mencari dan menggali materi pelajaran sendiri lalu menyampaikannya secara kreatif sehingga daya kreatif siswa semakin berkembang. Kedua, metode ini menempatkan guru sebagai fasilitator yang berperan mengarahkan siswa dan sebagai pembimbing bagi siswa.

Keberhasilan Metode Cooperative Learning tipe Jigsaw dipengaruhi kondisi siswa.Metode ini membutuhkan sikap siswa. Sikap yang dimaksudkan bukan sikap siswa terhadap mata pelajaran sejarah, melainkan sikap siswa selaku pembelajar terhadap siswa lain. Sikap ini yang dinamakan sikap sosial.Semakin tinggi sikap sosial siswa diperkirakan dapat menaikkan tingkat keberhasilan metode ini.Dengan berhasilnya metode ini, maka hasil belajar sejarah siswa meningkat.

Dua variabel diatas, yaitu metode pembelajaran dan sikap sosial merupakan dua faktor yang diduga mempengaruhi hasil belajar siswa.Merujuk penjelasan diatas, maka topik penelitian yang dilakukan adalah Pengaruh Metode Pembelajaran dan Sikap Sosial Terhadap Hasil Belajar Siswa SMA Negeri 12 Tangerang Selatan.

\section{Kajian Teoritik}

Hasil belajar menurut Bloom (Thobroni, 2012:23) adalah perubahan dalam tiga ranahyakni ranah kognitif, 
ranah afektif dan ranah psikomotorik. Maknanya, seseorang dapat dikatakan telah melakukan proses pembelajaran jika dalam dirinya telah terjadi perubahan dalam ketiga aspek tadi. Perubahan inilah yang dikategorikan sebagai hasil belajar.

Gagne (Suprijono, 2009: 5-6) mengatakan bahwa hasil belajar berupa informasi verbal, ketrampilan intelektual, strategi kognitif, ketrampilan motorik dan sikap. Bentuknya adalah kemampuan mengungkapkan pengetahuan dalam bentuk bahasa, memresentasikan konsep dan lambang, menyalurkan dan mengarahkan aktifitas kognitif, melakukan serangkaian gerakan jasmani, serta kemampuan menerima dan menolak objek berdasarkan penilaian terhadap objek tertentu.

Lindgren (Suprijono, 2009:7) menjelaskan bahwa hasil pembelajaran meliputi kecakapan, informasi, pengertian, dan sikap. Jadi hasil belajar dimunculkan dalam keseharian pembelajar dalam berbagai aktifitasnya yang menampakkan kecakapan, kemampuan menyerap dan menyampaikan kembali berbagai informasi yang diperoleh selama proses pembelajaran. Selain itujuga dinampakkan dalam sikap kesehariannya.

Hasil belajar, seperti halnya dikatakan oleh Cronbach (Sardiman, 2007: 40) ditunjukkan dengan adanya perubahan perilaku atau sikap sebagai hasil pengalaman. Setelah melalui proses pembelajaran, pembelajar harus menampakkan perubahan perilaku dan sikap dalam kehidupan kesehariannya. Perubahan perilaku dan sikap ini adalah bentuk nyata dari hasil belajar.

Hamalik (2004:31) menjelaskan bahwahasil belajar adalah pola-pola perbuatan, nilai-nilai, pengetahuanpengetahuan, sikap-sikap, apresiasi, abilitas, dan keterampilan Jadi hasil akhir dari sebuah pembelajaran, apapun bidang ajarnya, termasuk didalamnya Sejarah, pada dasarnya adalah adanya berbagai perubahan tingkah laku dalam diri siswa.

Hasil belajar sebenarnya merupakan hasil yang dicapai oleh siswa setelah mengikuti kegiatan belajar di kelas.Hasil belajar adalah suatu bukti keberhasilan belajar atau kemampuan seorang siswa dalam melakukan kegiatan belajarnya sesuai dengan bobot yang dicapainya. Kemampuan itu mencakup tiga domain, yaitu: kognitif, afektif dan psikomotor. Dengan demikian hasil belajar sejarah yang dimaksud dalam penelitian ini dapat diartikan sebagai tingkat kemampuan aktual yang dapat diukur berupa penguasaan ilmu pengetahuan, sikap, keterampilan dan sosial yang dicapai oleh siswa tentang kesejarahan sebagai hasil dari apa yang dipelajari di sekolah.

Pembelajaran membutuhkan metode agar tujuannya tercapai. Metode pembelajaran merupakan suatu cara atau strategi yang dilakukan oleh seorang guru agar terjadi proses belajar pada diri siswa untuk mencapai tujuan. Metode pembelajaran mencakup tiga strategi pokok pengorganisasian materi ajar, strategi penyampaian materi ajar, dan strategi pengelolaan pembelajaran. Metode pembelajaran yang baik adalah metode yang melibatkan peran aktif siswa dalam prosesnya. Metode Cooperative Learning tipe Jigsawadalah metode yang memenuhi kriteria ini.

Jigsaw telah dikembangkan dan diuji coba oleh Eliot Aronson dan temantemannya di Universitas Texas pada tahun 1970-an dan diadopsi oleh Slavin dan teman-temannya di Universitas John Hopkins. Pembelajaran menggunakan metodeCooperative Learning tipe Jigsaw melibatkan semua peserta didik yang ada di kelas. Tujuan dari metode ini adalah mengembangkan kerja tim, ketrampilan belajar kooperatif dan penguasaan materi.

Menurut Joyce \& Weil(Rusman, 2010: 133) Cooperative learning adalah suatu rencana atau pola yang digunakan untuk membentuk kurikulum (rencana 
pembelajaran jangka panjang), merancang bahan-bahan pembelajaran, dan membimbing pembelajaran di kelas ataupun yang lain.Cooperative learning biasanya disusun berdasarkan berbagai teori pengetahuanseperti prinsip pembelajaran, teori psikologis, sosiologis, analisis sistem atau teori lainnya yang mendukung.

Menurut Arends(Anita Lie, 2010: 28), Cooperative Lerning adalah pembelajaran dimana siswa didorong dan dituntut untuk mengerjakan tugas yang sama secara bersama-sama, dan mereka harus mengkoordinasikan usahanya untuk menyelesaikan tugas itu. Cooperative Learning berdasarkan atas falsafah homohomini socius, yang menekankan bahwa manusia adalah makluk sosial. Kerjasama merupakan kebutuhan penting bagi kehidupan manusia.

Cooperative learning merupakan landasan praktik pembelajaran hasil penurunan teori psikologi pendidikan dan teori belajar yang dirancang berdasarkan analisis terhadap implementasi kurikulum dan implikasinya pada tingkat operasional di kelas. Melalui cooperative learning guru dapat membantu siswa mendapatkan informasi, ide, keterampilan, cara berpikir, dan mengekpresikan ide. Cooperative learning dapat didefenisikan sebagai suatu pola yang menerangkan suatu proses penyebutan dan menghasilkan situasi lingkungan yang menyebabkan para siswa berinteraksi sehingga berinteraksi sehingga terjadi perubahan khususnya pada tingkah laku siswa. Cooperative learning mengandung strategi mengajar yaitu pola khusus kegiatan instruksional digunakan untuk mencapai tujuan belajar.

Cooperative Lerning dikembangkan oleh John Dewey dan Herbert Thelan. Menurut Dewey seharusnya kelas merupakan cermin masyarakat yang lebih besar.Thelan mengembangkan prosedur yang tepat untuk membantu para siswa untuk bekerja secara berkelompok. Tokoh lain adalah ahli Sosiologi Gordon Alrport yang mengingatkan kerjasama dan bekerja dalam kelompok akan memberikan hasil yang lebih baik. Menurut Sholmo Sharan dalam Cooperative Learning haruslah diciptakan setting kelas dan proses pengajaran kerja kelompok dan adanya persetujuan antar anggota dalam kelompok. Dalam cooperative learning koperatif memungkinkan siswa dapat belajar dengan cara bekerja sama dengan teman. Teman yang lebih mampu dalam kelompok dapat menolong teman yang lemah.Setiap anggota kelompok tetap memberi sumbangan pada prestasi kelompok.Para siswa juga mendapat kesempatan untuk bersosialisasi.

Keberhasilan Metode Cooperative Learning tipe Jigsawdipengaruhi oleh banyak hal, terutama kondisi siswa. Metode ini membutuhkan sikap siswa. Sikap yang dimaksudkan disini bukan sikap siswa terhadap mata pelajaran Sejarah, melainkan sikap siswa selaku pembelajar terhadap siswa lain. Sikap ini yang dinamakan sikap sosial. Semakin tinggi sikap sosial siswa diperkirakan akan menaikkan tingkat keberhasilan metode ini. Dengan berhasilnya metode ini, maka hasil belajar sejarah siswa akan meningkat.

Definisi tentang sikap disampaikan dalam beberapa versi oleh para ahli psikologi. Maio dan Haddock (Jenny Mercer \& Debbie Clayton, 2012:3) berpendapat bahwa sikap didefinisikan sebagai evaluasi menyeluruh terhadap suatu obyek berdasarkan informasi kognitif, afektif dan behavioral.Sikap seseorang terhadap suatu objek adalah perasaan mendukung atau memihak maupun perasaan tidak mendukung atau tidak memihak pada suatu objek.

Thurstone dalam Nina (2012:194) juga mengemukakan bahwa sikap merupakan penguatan positif atau negatif terhadap objek yang bersifat psikologis. Howard Kendler mengemukakan bahwa sikap 
merupakan kecenderungan (tendency) untuk mendekati (approach) atau menjauhi (avoid), serta melakukan sesuatu, baik secara positif maupun negatif terhadap suatu lembaga, peristiwa, gagasan atau konsep.

Menurut Fattah (2010:64) Sikap juga diartikan sebagai ungkapan rasa suka atau tidak suka terhadap isu, ide, orang, kelompok sosial. Oleh karena itu, objek sikap selalu berorientasi pada sosial.Dengan demikian, maka sikap selalu indentik dengan makna sikap sosial, yaitu respon evaluatif (positif atau negatif) seseorang terhadap nilainilai dalam masyarakat (kelompok) seperti keterbukaan, empati, komunikasi, kerjasama, sebagai hasil interaksi.

Robbins (2006:93) menyatakan bahwa sikap adalah pernyataan-pernyataan evaluatif, baik yang diinginkan atau tidak mengenai obyek, orang ataupun peristiwa. Sikap mencerminkan bagaimana seseorang merasakan sesuatu.

Sikap sosial terbentuk karena adanya interaksi sosial yang dialami oleh individu.Interaksi sosial mengandung arti lebih daripada sekedar adanya kontak sosial dan hubungan antar individu sebagai anggota kelompok sosial. Dalam interaksi sosial terjadi hubungan saling mempengaruhi antara individu yang satu dengan yang lain, terjadi hubungan timbal balik yang turut mempengaruhi pola prilaku masing-masing individu sebagai anggota masyarakat. Lebih dari itu, interaksi sosial meliputi hubungan individu dengan lingkungan fisik dan lingkungan psikologis yang dihadapinya.

\section{Tujuan Penelitian}

Secara operasional penelitian ini dilaksanakan untuk memperoleh informasi tentang :

a. Perbedaan hasil belajar sejarah siswa SMA yang mengikuti pembelajaran metode Cooperative Learning tipe Jigsaw dan yang mengikuti pembelajaran metode konvensional

b. Pengaruh interaksi antara penggunaan metode pembelajaran dan sikap sosial siswa SMA terhadap hasil belajar sejarah.

c. Perbedaan hasil belajar sejarah siswa SMA yang memiliki sikap sosial tinggi yang mengikuti metode Cooperative Learning tipe Jigsawdan yang mengikuti uj8jmetode pembelajaran konvensional

d. Perbedaan hasil belajar sejarah siswa SMA yang memiliki sikap sosial rendah yang mengikuti metode Cooperative Learning tipe Jigsawdan yang mengikuti metode pembelajaran konvensional

\section{B. Metodologi Penelitian}

Jenis penelitian ini adalah penelitian kuantitatif dengan menggunakan metode eksperimen dengan rancangan Treatment By Level $2 \times 2$ yang membandingkan dua metode pembelajaran yaitu Metode Cooperative Learning tipe Jigsawdan Konvensional dengan mempertimbangkan sikap sosial siswa dan pengaruhnya terhadap hasil belajar siswa.

Penelitian dilaksanakan di SMA Negeri 12 Kota Tangerang Selatan. Penelitian dilaksanakan dari bulan Januari sampai dengan April tahun 2014.Populasi penelitian ini adalah siswa kelas XI SMA Negeri 12 Kota Tangerang Selatan dengan jumlah keseluruhan 156 siswa, karena pembagian kelas di sekolah ini tidak dikelompokkan menurut tingkat prestasi, kelas bersifat homogen.Sebagai sampel diambil dua kelas.Sampel diambil secara nonprobabilitas dengan menggunakan pola purposive sampling.

Sampel jenis ini diambil dengan pertimbangan keterbatasan jumlah kelas paralel di SMA Negeri 12 Tangsel.Kelas XI di SMA Negeri 12 Tangsel hanya terdiri dari empat kelas, dengan rincian dua kelas jurusan IPA dan dua kelas jurusan IPS.Dengan pertimbangan keterbatasan inilah akhirnya yang diambil sebagai sampel adalah Kelas XI IPS. Kelas XI IPS 1 dijadikan kelas kontrol, 
sedangkan Kelas XI IPS 2 dijadikan kelas eksperimen.

Desain Penelitian dengan menggunakan rancangan Treatment by Level $2 \times 2$.Data dianalisis dengan teknik ANAVA dua jalur. Sebelum menguji hipotesis terlebih dahulu dilakukan pengujian persyaratan analisa. Uji persyaratan analisis meliputiUji Normalitas Data dan Uji Homogenitas Data

\section{Hasil Penelitian dan Pembahasan}

1. Deskripsi Data

a. Deskripsi Data Hasil Belajar Sejarah Siswa yang Pembelajarannya Menggunakan Metode Cooperative Learning tipe Jigsaw $\left(A_{1}\right)$

Data untuk variabel ini dinyatakan dalam skor yang diperoleh melalui penilaian terhadap hasil belajar Sejarah yang proses pembelajarannya menggunakan metodeCooperative Learning tipe Jigsaw. Penjabaran hasil belajar Sejarah siswa yang diberikan metode Cooperative Learning tipe Jigsawtanpa membedakan sikap sosial secara keseluruhan adalah sebagai berikut. Jumlah sampel adalah 18 orang siswa dengan rentang skor 16 dimana skor tertinggi 37 dan skor terendah 21.Rentang skor teoretiknya 0-40. Rerata skornya 29.17, Modus 33.83, Median 28,50, Varians 28.26, dan simpangan bakunya 5.32 .

b. Deskripsi Data Hasil Belajar Sejarah Siswa yang Pembelajarannya Menggunakan Metode Konvensional $\left(A_{2}\right)$

Hasil belajar sejarah siswa yang diajar dengan metode pembelajaran konvensional secara keseluruhan tanpa membedakan sikap sosial dapat dijelaskan sebagai berikut. Jumlah sampel adalah 18 orang siswa dengan rentang skor 14 dimana skor tertinggi 32 dan skor terendah 18.Rentang skor teoretiknya $0-40$.
Rerata skornya 25.50, Modus 27.50, Median 25,75, Varians 14.50, dan simpangan bakunya 3.81 .

c. Deskripsi Data Hasil Belajar Sejarah Siswa Dengan Sikap Sosial Positif dan Diajar dengan Metode Cooperative Learning tipe $\operatorname{Jigsaw}\left(\mathbf{A}_{1} \mathbf{B}_{\mathbf{I}}\right)$

Data untuk variabel ini dinyatakan dalam skor yang diperoleh melalui penilaian terhadap hasil belajar Sejarah siswa dengan sikap sosial positif yang pembelajarannya menggunakan metode Jigsaw. Data yang terkumpul menunjukkan hasilhasil sebagai berikut. Jumlah sampel 9 orang siswa dengan rentang skor 7 dimana skor tertinggi 37 dan skor terendah 30.Rentang skor teoretiknya $0-40$. Rerata skornya 33.89, Modus 32.83, Median 34,00, Varians 5.36, dan simpangan bakunya 2.32 .

d. Deskripsi Hasil Belajar Sejarah Siswa Dengan Sikap Sosial Negatif yang pembelajarannya menggunakan Metode Cooperative Learning tipe Jigsaw(A1 B2)

Data hasil belajar sejarah siswa dengan sikap sosial negatif bila diberikan metode pembelajaran Jigsawdapat dipaparkan sebagai berikut. Jumlah sampel adalah 9 orang siswa dengan rentang skor 6 dimana skor tertinggi 27 dan skor terendah 21.Rentang skor teoretiknya 0- 40. Rerata skornya 24.44, Modus 25.50, Median 25,00, Varians 4.53, dan simpangan bakunya 2.13 .

e. Deskripsi Hasil Belajar Sejarah Siswa dengan Sikap Sosial Positif yang Pembelajarannya Menggunakan Metode Konvensional $\left(A_{2} B_{1}\right)$

Data untuk variabel ini dinyatakan dalam skor yang diperoleh melalui penilaian hasil belajar Sejarah siswa dengan sikap 
sosial positif yang pembelajarannya mengunakan metodeKonvensional yangdapat digambarkan sebagai berikut: Jumlah sampel adalah 9 orang siswa dengan rentang skor 7 dimana skor tertinggi 25 dan skor terendah 18. Rentang skor teoretiknya 0-40. Rerata skor 22.44, Modus 23.50, Median 22,50, Varians 5.03 , dan simpangan baku 2.24.

f. Deskripsi Data Hasil Belajar Sajarah Siswa Dengan Sikap Sosial Negatif dan Pembelajaran Menggunakan Metode Konvensional $\left(\mathrm{A}_{2} \mathrm{~B}_{2}\right)$

Deskripsi hasil belajar sejarah siswa dengan sikap sosial negatif bila diberikan metode pembelajaran konvensional adalah sebagai berikut. Jumlah sampel adalah 9 orang siswa dengan rentang skor 7 dimana skor tertinggi 32 dan skor terendah 25.Rentang skor teoretiknya $0-40$. Rerata skornya 28.56, Modus 27.70, Median 28,00, Varians 4.78, dan simpangan bakunya 2.19 .

\section{Pengujian Hipotesis}

\section{a. Hipotesis Pertama}

Hipotesis pertama menyatakan terdapat perbedaan yang signifikan hasil belajar antara siswa yang mendapat pembelajaran dengan menggunakan metode Cooperative Learning tipe Jigsaw dan metode Konvensional.

Berdasarkan perhitungan ANAVA dua jalur diperoleh $\mathrm{F}_{\text {hitung }}$ untuk metode pembelajaran (dalam kolom) sebesar 24,575, sedangkan Ftabel $=4,15$ pada taraf nyata $\alpha=$ 0,05. Karena nilai $F_{\text {hitung }}>F_{\text {tabel }}$ maka hipotesis nol (Ho) ditolak dan $\mathrm{H}_{1}$ diterima dan menunjukkan bahwa terdapat perbedaan hasil belajar sejarah antara siswa yang mendapat pembelajaran dengan menggunakan metode pembelajaran Jigsawdan metode konvensional.

Uji Tuckey menunjukkan bahwa nilai $\mathrm{Q}_{\text {hitung }}=7,01$ yang yang lebih besar dari $\mathrm{Q}_{\text {tabel }}(0,05 ; 16 ; 2)=2,97$. Dengan demikian dapat disimpulkan bahwa hasil belajar sejarah siswa lebih baik dan berbeda signifikan untuk kelompok yang belajar dengan menggunakan metode Cooperative Learning tipe Jigsawdaripada yang menggunakan metode konvensional.

\section{b. Hipotesis Kedua}

Hipotesis kedua menyatakan terdapat pengaruh interaksi antara penggunaan metode pembelajaran dan sikap sosial siswa terhadap hasil belajar sejarah siswa.

Merujuk hasil perhitungan ANAVA dapat dilihat bahwa Fhitung untuk faktor interaksi yaitu 110,578 lebih besar daripada Ftabel yaitu 4,15 pada taraf nyata $\alpha=0,05$. Hal ini menunjukkan terdapat pengaruh interaksi antara penggunaan metode pembelajaran dan sikap sosial siswa terhadap hasil belajar sejarah siswa SMA.Dengan demikian maka $\mathrm{H}_{0}$ ditolak dan $\mathrm{H}_{1}$ diterima.

Hasil uji Tuckey menunjukkan bahwa Qhitung $=10,20$ dan 3,82 salah satunya Iebih besar dari Qtabel $(0,05 ; 2 / 18)=3,00$ yang berarti bahwa terdapat pengaruh interaksi yang signifikan antara penggunaan metode pembelajaran (Jigsawatau konvensional) dan sikap sosial siswa (tinggi atau rendah) terhadap hasil belajar sejarah siswa SMA

\section{c. Hipotesis Ketiga}

Hipotesa ketiga menyatakan terdapat perbedaan yang signifikan hasil belajar sejarah bagi siswa yang mempunya sikap sosial positif jika diberikan pembelajaran dengan metode Konvensional danmetode Cooperative Learning tipe Jigsaw. 
Nilai rerata hasil belajar sejarah siswa SMA yang memiliki sikap sosial positif bila diberikan metode Cooperative Learning tipe Jigsaw $\left(\mathrm{A}_{1} \mathrm{~B}_{\mathrm{I}}\right)$ adalah 33,89 . Sedangkan nilai rerata hasil belajar sejarah siswa SMA yang memiliki sikap sosial positif bila diberikan metode pembelajaran Konvensional $\left(A_{2} \mathrm{~B}_{1}\right)$ adalah 22,44.

Hasil uji Tuckey menunjukkan bahwa $\mathrm{Q}_{\text {hitung }}$ yaitu 15,47> Qtabel yaitu 3,95 pada taraf nyata $\alpha=0,05$. Dengan demikian maka dapat disimpulkan bahwa Ho ditolak dan $\mathrm{H}_{1}$ diterima yang berarti bahwa untuk siswa yang mempunyai sikap sosial positif, terdapat perbedaan hasil belajar sejarah siswa SMA yang signifikan antara yang diberikan pembelajaran dengan metode Konvensional dan metode Cooperative Learning tipe Jigsaw.

\section{d. Hipotesis Keempat}

Hipotesa keempat menyatakan terdapat perbedaan yang signifikan hasil belajar sejarah bagi siswa yang mempunya sikap sosial negatif jika diberikan pembelajaran dengan metode Konvensional dan metode Cooperative Learning tipe Jigsaw.

Nilai rerata hasil belajar sejarah siswa SMA yang memiliki sikap sosial negatif bila diberikan metode Cooperative Learning tipe Jigsaw $\left(\mathrm{A}_{1} \mathrm{~B}_{2}\right)$ adalah 24,44. Sedangkan nilai rerata hasil belajar sejarah siswa SMA yang memiliki sikap sosial negatif bila diberikan metode pembelajaran konvensional $\left(A_{2} \mathrm{~B}_{2}\right)$ adalah 28,56.

Hasil Uji Tuckey menunjukkan bahwa nilai $\mathrm{Q}_{\text {hitung }}=5,56>$ nilai $\mathrm{Q}_{\text {tabel }}=4,04$ untuk taraf nyata $\alpha=0,05$. Dengan demikian maka dapat disimpulkan bahwa Ho ditolak dan $\mathrm{H}_{1}$ diterima yang berarti bahwa untuk siswa yang mempunyai sikap sosial negatif, terdapat perbedaan hasil belajar sejarah siswa SMA yang signifikan antara yang diberikan pembelajaran dengan metode konvensional dan metode Cooperative Learning tipe Jigsaw.

\section{Pembahasan Hasil Penelitian}

Dari hasil analisis yang dilakukan melalui pengujian hipotesis, selanjutnya diberikan beberapa simpulan tentang hasil penelitian, yaitu sebagai berikut:

\section{a. Hipotesis Pertama}

Terdapat perbedaan yang signifikan hasil belajar antara siswa yang mendapat pembelajaran dengan menggunakan metode Cooperative Learning tipe Jigsaw dan metode Konvensional.

Berdasarkan perhitungan ANAVA dua jalur disimpulkan bahwa, Ho ditolak dan $\mathrm{H}_{1}$ diterima dan menunjukkan bahwa terdapat perbedaan hasil belajar sejarah antara siswa yang mendapat pembelajaran dengan menggunakan metode Cooperative Learning tipe Jigsawdan metode konvensional.

Jika dianalisis lebih jauh dengan menggunakan Uji Tuckey ternyata penggunaan metode Cooperative Learning tipe Jigsawmemiliki efek yang lebih tinggi bagi peningkatan hasil belajar sejarah siswa SMA.Siswa memperoleh hasil belajar sejarah yang lebih baik jika diberikan metode Cooperative Learning tipe Jigsaw.

Melalui metode Cooperative Learning tipe Jigsaw siswa dimotivasi untuk banyak membaca, apalagi jika siswa tersebut ditunjuk sebagai tim pakar. Sebagai anggota tim pakar, siswa harus memiliki kemampuan lebih dibanting yang lain. Pola diskusi dan tukar pikiran dalam masing-masing kelompok dalam metode Cooperative Learning tipe Jigsaw memaksa semua siswa untuk berani berbicara didepan siswa 
lainnya. Pada akhirnya, siswa yang pasif akan dipaksa untuk aktif, dalam pembelajaran. Hal ini memberikan efek positif bagi siswa, yaitu akan meningkatkan hasil belajarnya.

\section{b. Hipotesis Kedua}

Terdapat pengaruh interaksi antara penggunaan metode pembelajaran dan sikap sosial siswa terhadap hasil belajar sejarah siswa.

Berdasarkan perhitungan ANAVA dua jalur disimpulkan bahwa, Ho ditolak dan $\mathrm{H}_{1}$ diterima dan menunjukkan bahwa terdapat interaksi antara penggunaan metode pembelajaran dan sikap sosial terhadap hasil belajar sejarah.

Hasil Uji Tuckey untuk hipotesis kedua berhasil menolak hipotesis nol yang menyatakan bahwa tidak terdapat pengaruh interaksi.antara penggunaan metode pembelajaran dan sikap sosial siswa terhadap hasil belajar sejarah siswa SMA. Hal ini menunjukkan bahwa terdapat interaksi antara penggunaan metode Cooperative Learning tipe Jigsawdan konvensionaldan sikap sosial siswa terhadap hasil belajar sejarah siswa SMA.

\section{c. Hipotesis Ketiga}

Terdapat perbedaan yang signifikan hasil belajar sejarah bagi siswa yang mempunyai sikap sosial positif jika diberikan pembelajaran dengan metode Konvensional dan metode Cooperative Learning tipe Jigsaw.

Berdasarkan hasil perhitugan ANAVA dua jalur dapat disimpulkan bahwa Ho ditolak dan $\mathrm{H}_{1}$ diterima yang berarti bahwa untuk siswa yang mempunyai sikap sosial positif, terdapat perbedaan hasil belajar sejarah siswa SMA yang signifikan antara yang diberikan pembelajaran dengan metode Konvensional dan metode Cooperative Learning tipe Jigsaw. Hasil uji hipotesis ketiga menerima hipotesis yang menyatakan bahwa untuk siswa yang mempunyai sikap sosial positif, terdapat perbedaan yang signifikan hasil belajar sejarah siswa jika diberikan pembelajaran dengan metode Konvensionaldanmetode Cooperative Learning tipe Jigsaw.Hal ini menunjukkan bahwa siswa yang mempunyai sikap sosial positif, lebih cocok jika belajar dengan menggunakan metode Cooperative Learning tipe Jigsawdaripada menggunakan metode konvensional.

Jika dianalisis dengan menggunakan uji Tuckey, maka dapat dilihat bahwa penggunaan metode konvensionaluntuk siswa yang memiliki sikap sosial positif memiliki efek yang lebih kecili terhadap hasil belajar sejarah siswa jika dibandingkan dengan metode Cooperative Learning tipe Jigsaw.Dalam pembelajaran yang menggunakan metodeCooperative Learning tipe Jigsaw, siswa yang memiliki sikap sosial positif akan memiliki rasa percaya diri, jiwa kepemimpinan, serta rasa ingin tahu yang tinggi sehingga bisa memperdalam pemahaman melalui proses kerjasama tanpa harus selalu dibimbing oleh guru. Kondisi ini diakomodir oleh metode Cooperative Learning tipe Jigsaw.

\section{d. Hipotesis Keempat}

Terdapat perbedaan yang signifikan hasil belajar sejarah bagi siswa yang mempunya sikap sosial negatif jika diberikan pembelajaran dengan metode Konvensional dan metodeCooperative Learning tipe Jigsaw.

Hasil perhitungan dengan ANAVA dua jalur dapat disimpulkan 
bahwa terdapat pengaruh yang tidak signifikan pengunaan metode Cooperative Learning tipe Jigsawterhadap hasil belajar sejarah siswa mempunyai sikap sosial negatif.

Jika dianalisis lebih jauh dengan menggunakan Uji Tuckey ternyata penggunaan metode Cooperative Learning tipe Jigsawmemiliki efek yang lebih rendah bagi peningkatan hasil belajar sejarah siswa SMA.Siswa yang memiliki sikap sosial negatif memperoleh hasil belajar sejarah yang lebih rendah jika diberikan metode Cooperative Learning tipe Jigsawdaripada jika diberikan metode pembelajaran konvensional.

Siswa yang memiliki sikap sosial negatif apabila diberikan pembelajaran menggunakan metode konvensionalhasil belajarnya lebih tinggidaripada diberikan pembelajaran menggunakan metode Cooperative Learning tipe Jigsaw. Hal ini disebabkan karena dalam pembelajaran dengan menggunakan metode konvensional,guru berperan lebih besar dibandingkan dengan metode Cooperative Learning tipe Jigsaw. Siswa yang memiliki sikap sosial negatif akan merasa lebih terbimbing dan lebih percaya diri, karena peran guru sangat dominan.

Sebaliknya siswa yang memiliki sikap sosial negatif apabila diberikan pembelajaran menggunakan metode Cooperative Learning tipe Jigsawhasilnya lebih rendah. Jika menggunakan metode Cooperative Learning tipe Jigsawini, siswa yang memiliki sikap sosial negatif ternyata tidat termotivasi oleh metode Cooperative Learning tipe Jigsaw, akibatnya hasil belajar juga rendah.

\section{Kesimpulan}

Berdasarkan hasil pengujian hipotesis, kesimpulan penelitian ini sebagai berikut :

a. Hasil belajar sejarah siswa SMA yang menggunakan pembelajaran dengan metode Cooperative Learning tipe Jigsawlebih tinggi dari siswa yang menggunakan metode pembelajaran konvensional.

b. Terdapat pengaruh interaksi antara metode pembelajaran dan sikap sosial terhadap hasil belajar sejarah siswa SMA.

c. Terdapat perbedaan yang signifikan dimana hasil belajar sejarah siswa SMA yang memiliki sikap sosial positif dan menggunakan metode Cooperative Learningtipe Jigsawlebih tinggi dari siswa SMA yang memiliki sikap sosial positif dan menggunakan metode pembelajaran konvensional.

d. Terdapat perbedaan yang signifikan dimana hasil belajar sejarah siswa SMA yang memiliki sikap sosial negatif dan menggunakan metode pembelajaran konvensional lebih tinggi dari siswa SMA yang memiliki sikap sosial negatif dan menggunakan metode Cooperative Learning tipe Jigsaw.

Berdasarkan hasil penelitian dan simpulan yang telah diuraikan di atas, berikut ini diajukan beberapa rekomendasi sebagai berikut:

1. Guru sejarah SMA dapat menggunakan metode Cooperative Learning tipe Jigsaw dalam pembelajaran agar hasil belajarnya lebih baik.

2. Dalam menerapkan metode pembelajaran hendaknya guru mempertimbangkan sikap sosial siswa. Sikap sosial siswa bisa diperoleh dengan cara memberikan quesioner sebelum pembahasan materi dimulai. Setelah mengetahui sikap 
sosial siswa, guru dapat memilih metode pembelajaran mana yang dapat mengakomodir sikap sosial siswa tersebut, sehingga dapat meningkatkan basil pembelajaran.

3. Jika guru mendapatkan siswa yang memiliki sikap sosial positif, sebaiknya metode Cooperative Learning tipe Jigsaw digunakan dalam pembelajaran sehingga mendapatkan hasil belajar yang lebih balk.

4. Jika guru mendapatkan bahwa siswanya memiliki sikap sosial negatif, sebaiknya metode Konvensional yang digunakan dalam pembelajaran untuk memperoleh hasil belajar sejarah yang lebih baik.

\section{Daftar Pustaka}

Anita Lie. 2008, Cooperatif Learning, Mempraktekan Cooperatif Learning diruang-ruang Kelas. Jakarta : Grasindo.

Dick, W and L. Carey. 2008, The Systematic Designs of Instructional Tallahase Florida: Harpers Collins Publisher.

Slavin E Robert. 2009, Cooperatif Learning Teori, Riset dan Praktik.Bandung Nusa Media.

Suprijono, Agus. 2013, Cooperative Learning: Teori dan Aplikasi PAIKEM. Yogyakarta: Pustaka Pelajar.

Thobroni, Muhammad. 2011, Belajar dan Pembelajaran. Jogyakarta: Ar-Ruzz Media. 